\title{
Aplikasi Pendeteksi Kualitas Daging Menggunakan Segmentasi Region of Interest Berbasis Mobile
}

\author{
Rismawan Fajril Falah ${ }^{1)}$, Oky Dwi Nurhayati ${ }^{2)}$, Kurniawan Teguh Martono ${ }^{2)}$ \\ Program Studi Sistem Komputer, Fakultas Teknik, Universitas Diponegoro \\ Jalan Prof. Sudharto, Tembalang, Semarang, Indonesia
}

\begin{abstract}
Abstrak - Peningkatan kebutuhan daging sapi di Indonesia saat ini dimanfaatkan pedagang-pedagang curang untuk mengambil banyak keuntungan. Penjualan daging sapi berkualitas buruk menimbulkan kecemasan bagi masyarakat karena kandungan yang sangat berbahaya. Kualitas daging sapi yang baik dapat ditentukan dari warna, bau, tekstur dan kenampakan. Masyarakat pada umumnya menggunakan penglihatan kasat mata untuk menentukan kualitas daging sapi. Namun cara tersebut masih kurang efektif karena mata memiliki kelemahan untuk melihat suatu objek secara detail. Penelitian ini bertujuan merancang dan membuat aplikasi untuk mendeteksi kualitas daging sapi dengan menggunakan proses pengolahan citra.
\end{abstract}

Aplikasi dibuat menggunakan sistem operasi Android yang terintegrasi dengan SDK Android, library OpenCV dan Eclipse. Proses deteksi dilakukan dengan cara pengambilan gambar daging sapi dan diolah dengan beberapa tahap pengolahan citra digital. Tahap pengolahan terdiri dari pra pengolahan citra aras keabuan, segmentasi Region of Interest, ekualisasi histogram dan analisis nilai statistik ekstraksi ciri.

Penentukan kualitas daging sapi yang lebih efektif dapat dilakukan dengan melihat hasil analisis pengolahan citra. Penelitian ini menunjukkan hasil analisis akurasi ketepatan baca aplikasi adalah 90\%.

Kata Kunci: Android, Ekstraksi Ciri, OpenCV, Pengolahan Citra, Region of Interest

\section{Pendahuluan}

$\mathrm{D}$ aging sapi merupakan salah satu bahan makanan yang penting untuk memenuhi kebutuhan gizi salah satunya protein. Kandungan gizi yang tinggi pada daging sapi sangat bermanfaat bagi pertumbuhan manusia. Dari kandungan tersebut, daging sapi merupakan salah satu bahan makanan yang sangat digemari didunia terutama di Indonesia. Peningkatan konsumsi daging sapi di Indonesia sangat signifikan setiap tahunnya. ${ }^{[1]}$
Dari fenomena tersebut banyak sekali hal-hal yang dilakukan oleh pedagang atau penjual daging sapi konsumsi untuk meraup banyak keuntungan dengan mengesampingkan kualitas daging yang layak untuk dikonsumsi. Untuk meminimalisir kerugian yang dihasilkan, masyarakat membutuhkan pengetahuan lebih mengenai kondisi-kondisi daging sapi yang dijual apakah berkualitas baik atau buruk.

Saat ini sud ah banyak teknologi yang berkembang seperti komputer, smartphone atau ponsel pintar yang sudah menjadi kebutuhan primer untuk dapat digunakan sebagai media informasi instan. Namun permasalahan yang terjadi adalah keterbatasan masyarakat yang kurang memiliki kemampuan untuk melihat kualitas daging yang baik dan hanya mengandalkan informasi dari luar saja. Untuk itu diperlukan sebuah aplikasi yang mampu membaca kualitas daging secara langsung melalui ponsel yang dimiliki oleh calon pembeli daging tersebut.

Dalam pengembangan aplikasi pendeteksi kualitas daging sapi, metode yang digunakan yaitu Region of Interest (ROI). Metode ROI cocok diterapkan untuk deteksi kualitas daging karena mampu menonjolkan area tertentu dari citra digital yang di anggap lebih penting untuk membuat tampilan lebih jelas dari aslinya. ${ }^{[2]}$ Metode ini nantinya akan diterapkan pada perangkat ponsel pintar menggunakan Sistem Operasi Android dan library OpenCV pada editor Eclipse. Citra yang diambil dapat dilakukan melalui pengambilan gambar dari kamera secara langsung maupun dari sampel citra yang sudah ada sebelumnya.

Dengan membangun aplikasi pendeteksi kualitas daging sapi, diharapkan masyarakat lebih mudah untuk melakukan pengecekan sendiri secara langsung melalui ponsel pintarnya untuk daging yang berkualitas baik atau buruk dengan mengambil sampel gambar daging sapi yang di inginkan.

Dalam pembuatan tugas akhir ini pembahasan masalah memiliki batasan pada permasalahan berikut.

1. Pembuatan aplikasi yang dapat mendeteksi kualitas daging dengan Ekualisasi Histogram dan pemilihan area yang diinginkan (Region of Interest).

2. Perancangan dan pembuatan aplikasi menggunakan editor Eclipse Juno yang dijalankan dari sistem operasi Windows 8 dan menggunakan library OpenCV v2.4.11. 
3. Aplikasi diterapkan dalam ponsel pintar bersistem operasi android versi Froyo 2.2 hingga versi Lolipop 5.0.2.

4. Aplikasi dibuat untuk penelitian dan tidak dipublikasikan secara meluas.

5. Penelitian dilakukan dengan menggunakan 20 sampel data dan dibandingkan dengan aplikasi yang sudah ada.

6. Pengujian dilakukan pada daging sapi yang diambil citranya menggunakan kamera berukuran 4 dan 5 megapiksel dengan jarak 20 dan $30 \mathrm{~cm}$.

\section{TINJAUAN PUSTAKA}

\section{A. Daging Sapi}

Daging adalah semua jaringan hewan dan semua produk hasil pengolahan jaringan-jaringan tersebut yang dapat dimakan serta tidak menimbulkan gangguan kesehatan bagi yang mengkonsumsinya. Organ-organ misalnya hati, paru-paru, limpa, pankreas, otak, jantung, ginjal dan jaringan otot termasuk dalam definisi ini. ${ }^{[3]}$

Daging dalam arti khusus sebagai bagian dari hewan yang digunakan sebagai makanan. Pada praktiknya, definisi ini terbatas hanya pada beberapa lusin dari sekitar 3000 spesies mamalia. Pengertian daging juga dapat diperluas mencakup organ-organ seperti hati, ginjal, otak dan jaringan lain yang dapat dimakan. ${ }^{[4]}$

Daging sapi berdasarkan SNI adalah bagian otot skeletal dari karkas sapi yang aman, layak dan lazim dikonsumsi oleh manusia dapat berupa daging segar, daging segar dingin, atau daging beku. ${ }^{[5]}$

Ciri-ciri spesifik daging sapi yang sehat adalah berwarna merah terang/cerah, mengkilap, tidak pucat, elastis,tidak lengket dan beraroma "khas". Sifat spesifik sensori yang dimiliki daging dapat menentukan daya terima bagi konsumen. ${ }^{[6]}$

\section{B. Pengolahan Citra Digital}

Pengolahan citra adalah pemrosesan citra, khususnya dengan menggunakan komputer, menjadi citra yang kualitasnya lebih baik. Pengolahan Citra bertujuan memperbaiki kualitas citra agar mudah diinterpretasi oleh manusia atau mesin. Teknik-teknik pengolahan citra mentransformasikan citra menjadi citra lain. Jadi, masukannya adalah citra dan keluarannya juga citra, namun citra keluaran mempunyai kualitas lebih baik daripada citra masukan.

Suatu citra dapat didefinisikan sebagai fungsi $f(x, y)$ berukuran $\mathrm{M}$ baris dan $\mathrm{N}$ kolom, dengan $\mathrm{x}$ dan $\mathrm{y}$ adalah koordinat $\mathrm{f}$ di titik koordinat $(x, y)$ dinamakan intensitas atau tingkat keabuan dari citra pada titik tersebut. Apabila nilai $x, y$ dan nilai f secara keseluruhan berhingga (finite) dan bernilai diskrit maka dapat dikatakan bahwa citra tersebut adalah citra digital. Gambar 1 menunjukkan posisi koordinat digital- ${ }^{[7]}$

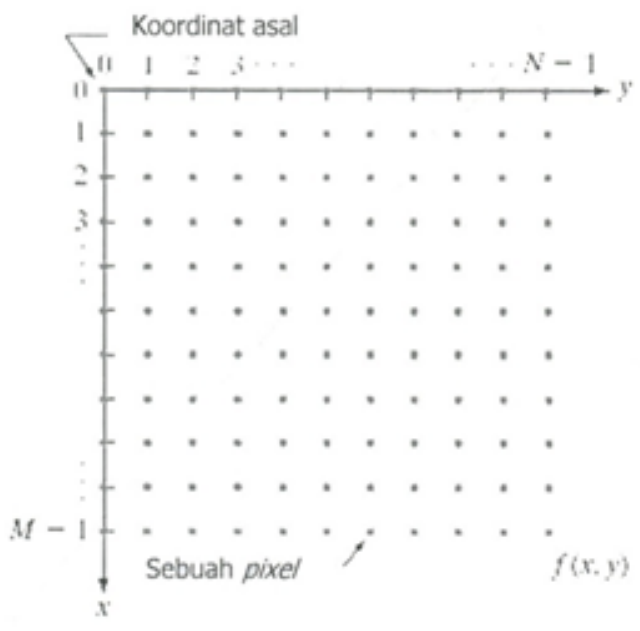

Gambar 1 Koordinat citra Digital

\section{Ekualisasi Histogram}

Ekualisasih histogram (Histogram Equalization) merupakan salah satu bagian dari beberapa aplikasi pengolahan citra. Tujuan dari teknik ini adalah untuk menghasilkan histogram citra yang seragam. Teknik ini dapat dilakukan pada keseluruhan citra atau beberapa bagian citra saja.

Histogram hasil proses ekualisasi tidak akan seragam atau sama untuk seluruh intensitas. Teknik ini hanya melakukan distribusi intensitas dari histogram awal. Jika histogram awal memiliki beberapa puncak dan lembah maka histogram hasil ekualisasi akan tetap memiliki puncak dan lembah . akan tetapi puncak dan lembah tersebut akan digeser. Histogram hasil ekualisasi akan lebih disebarkan (spreading). ${ }^{[7]}$

\section{Region of Interest (ROI)}

Segmentasi merupakan teknik untuk membagi suatu citra menjadi beberapa daerah (region) dimana setiap daerah memiliki kemiripan atribut. ${ }^{[7]}$ Level untuk pembagian tergantung pada masalah yang diselesaikan. Segmentasi seharusnya berhenti ketika objek yang diinginkan dalam aplikasi telah terisolasi. Yang diinginkan adalah citra produk dengan tujuan untuk mengetahui ada tidaknya penyimpangan tertentu. ${ }^{[8]}$

Region of Interest (ROI) merupakan salah satu proses pengolahan citra dimana pengguna mampu mengolah citra yang mengandung informasi data citra yang dikehendaki. ${ }^{[2]}$ ROI bekerja dalam pengkodean secara berbeda pada area tertentu dari citra digital sehingga kualitas yang lebih baik dari area sekitarnya. Proses ini sangat penting bila terdapat area tertentu dari citra yang dirasa lebih penting dari bagian lainnya. Area penting tersebut selanjutnya dapat digunakan untuk pengolahan dengan metode tertentu sesuai dengan keperluan penggunaan.

\section{E. Ekstraksi Ciri}

Ekstraksi ciri adalah proses mengambil ciri-ciri yang terdapat pada objek didalam citra untuk mengenali objek tersebut. Ekstraksi ciri merupakan langkah awal dalam melakukan klasifikasi dan interpretasi citra. Proses ini berkaitan dengan kuantisasi karakteristik citra 
ke dalam sekelompok nilai ciri yang sesuai. Ciri-ciri umum yang digunakan untuk mengenali satu atau beberapa objek didalam citra adalah ukuran, posisi atau lokasidan orientasi atau sudut kemiringan objek terhadap garis acuan yang digunakan. Salah satu metode yang digunakan pada ekstraksi ciri adalah ekstraksi ciri statistik orde pertama. ${ }^{[9]}$

Dari nilai-nilai pada histogram yang dihasilkan, dapat dihitung beberapa parameter ciri statistik orde pertama dalam penelitian ini antara lain adalah rata-rata (mean) dan standar deviasi. ${ }^{[7]}$

1. Mean $(\mu)$

Menunjukkan ukuran dispersi dari suatu citra seperti persamaan (1).

$$
\mu=\sum_{n} f_{n} p\left(f_{n}\right)
$$

Dimana $f_{n}$ merupakan suatu nilai intensitas keabuan, sementara $p\left(f_{n}\right)$ menunjukkan nilai histogramnya (probabilitas kemunculan intensitas tersebut pada citra).

2. Standar Deviasi $(\sigma)$

Standar Deviasi adalah salah satu teknik statistik yang digunakan untuk menjelaskan homognitas kelompok yang ditunjukkan seperti persamaan (2).

$$
\sigma=\frac{1}{N-1} N_{i=1} X_{i}-\mu^{2}
$$

Dimana $\sigma$ merupakan nilai standar deviasi. $N$ merupakan jumlah total piksel, $X_{i}$ nilai piksel pada posisi ke-i dan $\mu$ merupakan nilai rata-rata piksel.

\section{F. Android}

Android merupakan sistem operasi yang berisi middleware serta aplikasi-aplikasi dasar. Basis sistem operasi android yaitu kernel linux 2.6 yang telah diperbarui untuk perangkat bergerak. Pengembangan aplikasi android menggunakan Bahasa pemrograman java. Yang mana konsep-konsep pemrograman java berhubungan dengan Pemrograman Berbasis Objek (OOP). Selain itu pula dalam pengembangan aplikasi android membuutuhkan software development kit (SDK) yang disediakan android, SDK ini memberi jalan bag $i$ programmer untuk mengakses Application Programming Interface (API) pada android. ${ }^{[10]}$

\section{G. Eclipse Juno}

Eclipse Juno merupakan salah satu versi dari sebuah IDE (Integrated Development Environment) untuk mengembangkan perangkat lunak dan dapat dijalankan di semua platform (platform-independent). [11]

\section{H. OpenCV 2.4.11}

Open CV (Open Computer Vision) adalah sebuah API (Application Programming Interface) Library yang sudah sangat familiar pada Pengolahan Citra Computer Vision. Computer Vision itu sendiri adalah salah satu cabang dari Bidang Ilmu Pengolahan Citra (Image Processing) yang memuingkinkan komputer dapat melihat seperti manusia. Dengan vision tersebut komputer dapat mengambil keputusan, melakukan aksidan mengenali terhadap suatu objek. Beberapa pengimplementasian dari Computer Vision adalah Face
Recognition, Face Detection, Face/Object Tracking, Road Trackingdan lainnya. ${ }^{[12]}$

\section{PERANCANGAN Sistem}

Perancangan sistem dalam penelitian ini menjelaskan mengenai kebutuhan sistem, prosedur pengembangan perangkat lunak serta perancangan sistem dan antarmuka aplikasi pengolahan citra.

\section{A. Kebutuhan Sistem}

Dalam penelitian dan pembuatan aplikasi pendeteksi kualitas daging berbasis perangkat bergerak android, terdapat kebutuhan sistem yang digunakan untuk menunjang setiap tahap proses pembuatannya seperti perangkat lunak dan perangkat keras. Berikut merupakan kebutuhan sistem yang digunakan :

1. Perangkat Lunak

Perangkat lunak yang digunakan untuk penelitian dan pembuatan aplikasi adalah :

- Sistem Operasi Microsoft Windows 8 Pro 64 bit.

- Fiji (ImageJ)

- Eclipse Juno

- Open CV 2.4.11

- Corel Draw X4

- Microsoft Word 2013

- Android OS, v5.0.2 (Lolipop)

2. Perangkat Keras

- Laptop Asus X201E

- Ponsel Pintar Xiaomi Mi4i

\section{B. Prosedur Pengembangan Perangkat Lunak}

Perancangan sistem aplikasi perangkat bergerak dibutuhkan tahap prosedur pengembangan perangkat lunak. Tahap ini sangat penting untuk menentukan setiap proses berjalannya aplikasi yang akan dibuat. Tahap-tahap dapat dilakukan dengan menggunakan diagram blok maupun diagram alir.

1. Diagram Blok Algoritma Program

Algoritma program dalam perancangan sistem dibuat menggunakan diagram blok. Diagram ini digunakan untuk menentuka setiap tahapan sistem didalam aplikasi saat dijalankan dari awal hingga proses selesai. Diagram dapat ditunjukkan pada Gambar 2.

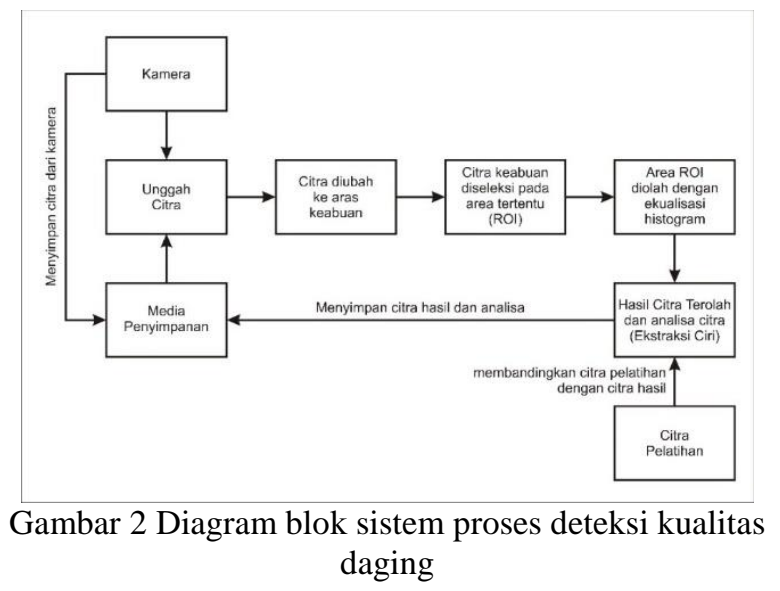

Pada diagram blok yang dirancang merupakan proses algoritma didalam aplikasi pendeteksi kualitas daging dari awal hingga sistem selesai. Pada tahap awal 
dilakukan pengambilan sampel citra daging dengan mengunggah citra dari kamera ponsel atau media penyimpanan pada ponsel. Citra yang sudah diunggah kemudian kemudian diubah ke citra aras keabuan 8 bit untuk pemrosesan citra yang lebih akurat. Hasil citra aras keabuan tersebut diseleksi berdasarkan area yang diminati (Region of Interest). Area terseleksi tersebut selanjutnya diolah menggunakan ekualisasi histogram untuk menonjolkan area tersebut. Setelah hasil citra terolah didapat, dilakukan proses analisa menggunakan ekstraksi fitur untuk menentukan kualitas citra tersebut serta membandingkan dengan citra pelatihan yang sebelumnya sudah dilakukan. Perbandingan tersebut menentukan hasil kualitas citra daging tersebut (baik atau buruk). Hasil analisa yang sudah dilakukan dapat disimpan kedalam memori media penyimpanan untuk dokumentasi.

2. Diagram Alir Perangkat Lunak

Diagram alir perangkat lunak menunjukkan proses untuk menjalankan aplikasi secara keseluruhan. Tahap dilakukan dari proses membuka hingga proses pendeteksian. Diagram alir aplikasi pendeteksi kualitas daging ditunjukkan pada Gambar 3.

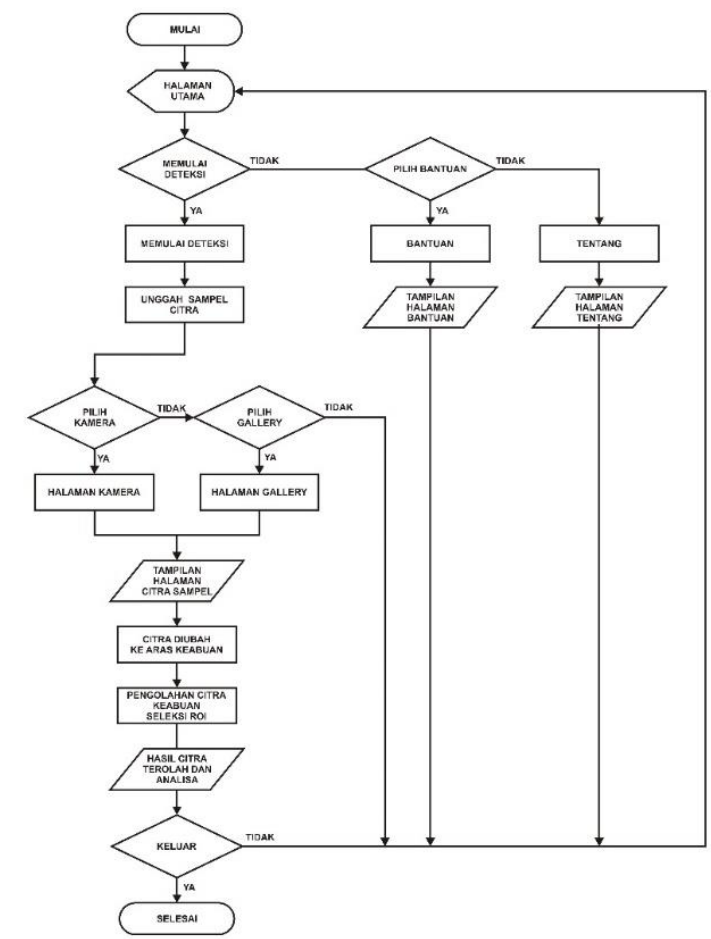

Gambar 3 Diagram Alir Aplikasi Deteksi Kualitas Daging

Aktivitas dalam diagram alir yang sirancang merupakan aktivitas dari aplikasi pada saat digunakan oleh pengguna dari tampilan saat dibuka hingga tampilan akhir. Pada saat dimulai membuka aplikasi, pengguna langsung dihadapkan pada sebuah tampilan halaman utama yang berisi logo aplikasidan tomboltombol menu utama (Memulai Deteksi, Bantuan, Tentangdan Keluar).

Untuk memulai proses mendeteksi kualitas daging, pengguna memilih tombol Memulai Deteksi. Pengguna akan diarahkan pada halaman Unggah Citra dimana pengguna harus mengambil citra sampel. Pengguna akan mendapat 2 (dua) pilihan, yaitu mengunggah citra melalui kamera dan memotret sampel secara langsung atau mengambil sampel citra yang sudah ada pada media penyimpanan ponsel. Proses berikutnya aplikasi akan menampilkan citra asli dan citra asli yang sudah diubah ke citra aras keabuan 8 bit. Setelah itu citra aras keabuan tersebut diseleksi pada area tertentu (Region of Interest). Pada pengolahan akhir pengguna dihadapkan pada halaman analisa berupa hasil citra terolah dan juga analisanya.

Pada bagian Bantuan terdapat halaman yang berisi tahapan tahapan proses dan cara kerja aplikasi deteksi kualitas daging. Selain itu terdapat bagian Tentang yang berisi informasi dari aplikasi secara keseluruhan.

\section{Perancangan Antarmuka Perangkat Lunak}

Perancangan antarmuka atau tampilan sangat diperlukan untuk memberikan suatu gambaran serta penjelasan dari setiap proses berjalannya aplikasi dari awal hingga selesai. Perancangan ini memuat isi dari setiap halaman yang ditampilkan seperti kegunaan tombol, teks dan gambar. Fungsi dari perancangan ini adalah untuk memberikan antarmuka aplikasi yang lebih menarik dan terstruktur agar lebih mudah dipahami saat dioperasikan.

1. Antarmuka Halaman Menu Utama

Halaman utama aplikasi menunjukkan tampilan awal saat aplikasi dibuka seperti ditunjukkan pada Gambar 4

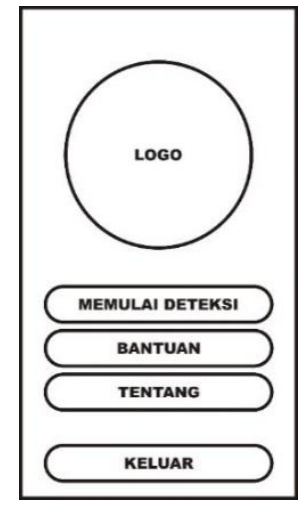

Gambar 4 Antarmuka Halaman Utama

2. Antarmuka Halaman Unggah Citra

Halaman ini menunjukkan tampilan proses pengunggahan data citra daging yang akan digunakan seperti ditunjukkan pada Gambar 5.

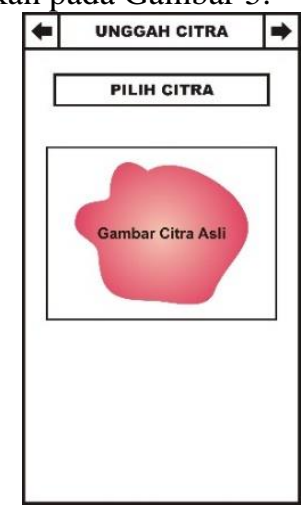

Gambar 5 Antarmuka Halaman Unggah Citra 
3. Antarmuka Halaman Pra Pengolahan

Halaman ini menunjukkan tampilan proses pengunggahan data citra daging yang akan digunakan seperti ditunjukkan pada Gambar 6.

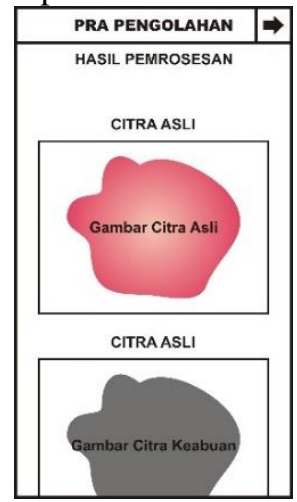

Gambar 6 Antarmuka Halaman Pra Pengolahan

4. Antarmuka Halaman Seleksi Citra

Halaman ini merupakan halaman yang berisi proses utama dari aplikasi pendeteksi daging seperti ditunjukkan pada Gambar 7.

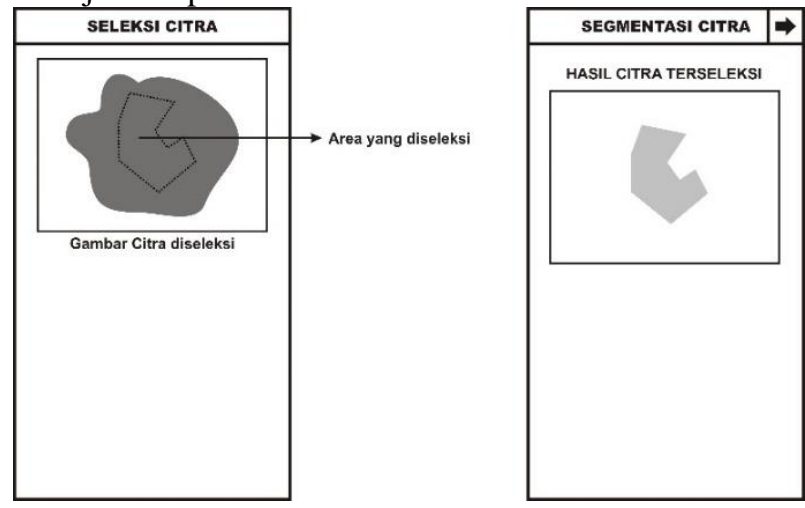

Gambar 7 Antarmuka Halaman Seleksi Citra

\section{Antarmuka Halaman Analisa}

Halaman ini merupakan halaman yang berisi analisa dari citra daging terolah berupa gambar dan hasil kualitas citra seperti ditunjukkan pada Gambar 8.

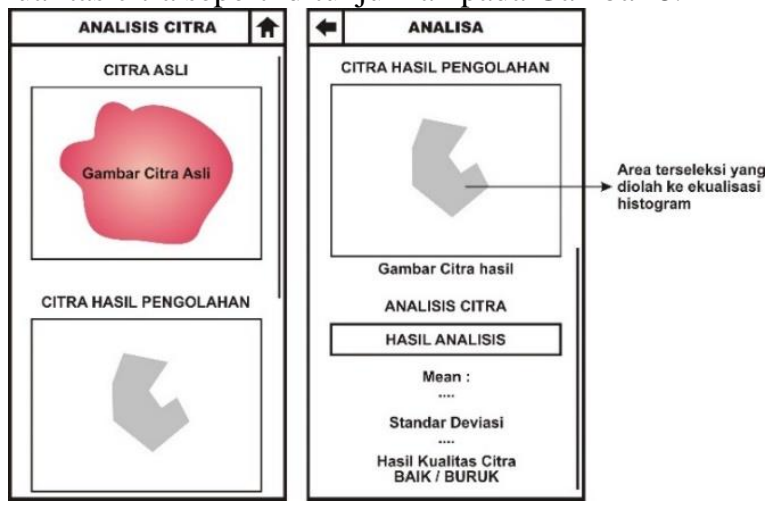

Gambar 8 Antarmuka Halaman Analisa

\section{IMPLEMENTASI DAN PENGUJIAN}

\section{A. Implementasi Antarmuka Perangkat Lunak}

Proses pembuatan aplikasi dilakukan secara berurutan sesuai dengan kebutuhan dari penelitian. Salah satu hal utama dalam pembuatan aplikasi adalah bagian antarmuka untuk memberikan interaksi yang mampu dimengerti oleh pengguna. Terdapat beberapa langkah dalam proses kerja Pendeteksi Kualitas Daging melalui antarmuka aplikasi.

1. Tampilan Halaman Utama

Tampilan awal dalam aplikasi pendeteksi kualitas daging menunjukkan halaman menu utama. Halaman ini berisi beberapa tombol yang ditunjukkan pada gambar 9.

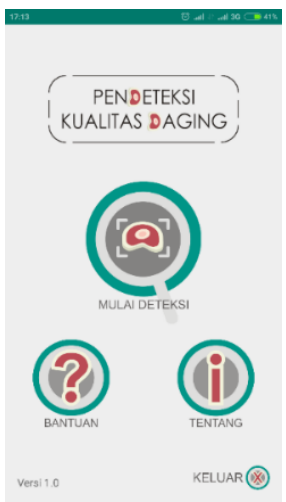

Gambar 9 Tampilan Halaman Utama

Pada halaman ini terdapat logo tampilan pada bagian atas. Selain itu terdapat 4 (empat) tombol atau button yang berfungsi sama sebagai penunjuk untuk mengarahkan pengguna pada halaman berikutnya sesuai dengan nama tombol tersebut. Tombol Mulai Deteksi, Tombol Bantuan, Tombol Tentangdan Tombol keluar.

2. Tampilan Unggah Citra

Tampilan Unggah Citra akan muncul setelah menekan tombol mulai deteksi pada tampilan halaman utama. Tampilan ini dalam aplikasi pendeteksi kualitas daging menunjukkan halaman untuk citra yang akan di unggah kedalam aplikasi yang ditunjukkan pada gambar 10 .

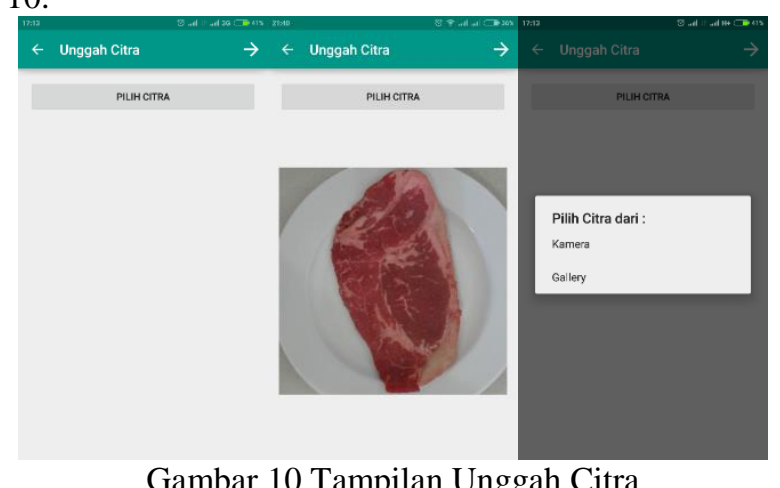

Pada halaman ini terdapat tombol dan area tampil citra pada bagian halaman utama. Tombol pilih citra saat ditekan akan menampilkan pop-up yang berisi pilihan pengunggahan citra (Unggah dari kamera atau dari Gallery). Area tampil citra merupakan tempat citra yang sudah dipilih sebelumnya akan ditampilkan berupa imageView. Berbeda dengan halaman utama, pada halaman unggah citra terdapat Action Bar yang berfungsi sebagai area navigasi dan judul halaman.

3. Tampilan Pra Pengolahan

Tampilan Pra Pengolahan akan muncul setelah menekan tombol panah $\rightarrow$ pada tampilan halaman unggah citra. Tampilan ini dalam aplikasi pendeteksi kualitas daging menunjukkan proses awal yaitu pra pengolahan citra yang ditunjukkan pada gambar 11 . 


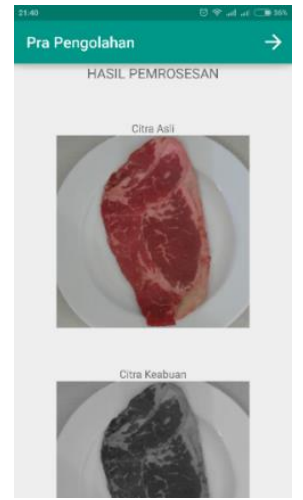

Gambar 11 Tampilan Pra Pengolahan

Pada halaman ini terdapat 2 (dua) buah citra berupa imageView yang ukurannya menyesuaikan dengan citra yang sudah di unggah sebelumnya yang berisi Citra asli dan citra asli yang diubah ke aras keabuan.

\section{Tampilan Seleksi Citra}

Tampilan Seleksi Citra akan muncul setelah menekan tombol panah $\rightarrow$ pada tampilan halaman pra pengolahan citra. Tampilan ini dalam aplikasi pendeteksi kualitas daging menunjukkan proses berikutnya yaitu seleksi citra berupa proses pemilihan area yang dinginkan (Region of Interest) untuk diolah ke proses selanjutnya yang ditunjukkan pada gambar 12 .

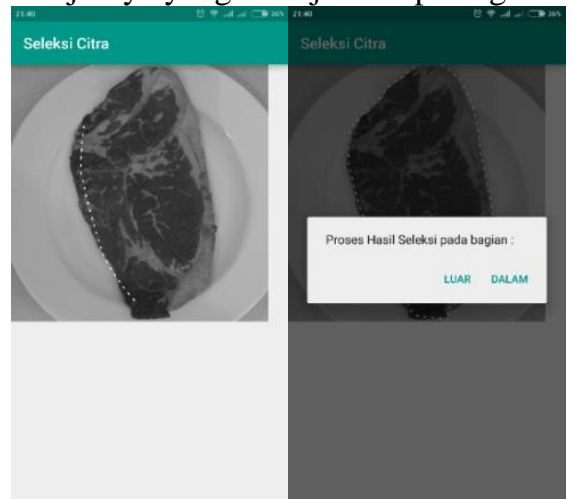

Gambar 12 Tampilan Seleksi Citra

Pada halaman ini memiliki fungsi khusus untuk melakukan proses seleksi citra Pemilihan area dapat dilakukan dengan cara menyentuh dan menggeser sentuhan pada citra sesuai keinginan yang dapat ditunjukkan dengan garis putus-putus berwarna putih mengikuti sentuhan. Setelah area terpilih akan muncul рор-ир berupa pilihan proses seleksi pada bagian tertentu.

5. Tampilan Segmentasi Citra

Tampilan Segmentasi Citra akan muncul setelah memilih pop-up pada halaman seleksi citra. Tampilan ini memunculkan hasil area yang di seleksi pada halaman sebelumnya sesuai pilihan yang sudah ditentukan (seleksi pada bagian dalam atau luar) yang ditunjukkan pada gambar 13 .

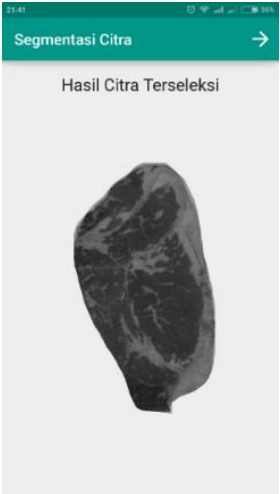

Gambar 13 Tampilan Segmentsai Citra

Pada halaman ini memiliki untuk menampilkan hasil seleksi citra dan proses segmentasi. Hasil yang ditampilkan adalah 1 (satu) imageView yang menunjukkan citra terseleksi dengan menghilangkan area yang tidak dipilih.

6. Tampilan Analisis Citra

Tampilan Analisis Citra akan muncul setelah setelah menekan tombol panah $\rightarrow$ pada tampilan halaman segmentasi citra. Tampilan ini memunculkan hasil akhir dari pengolahan citra yang ditunjukkan pada gambar 14.

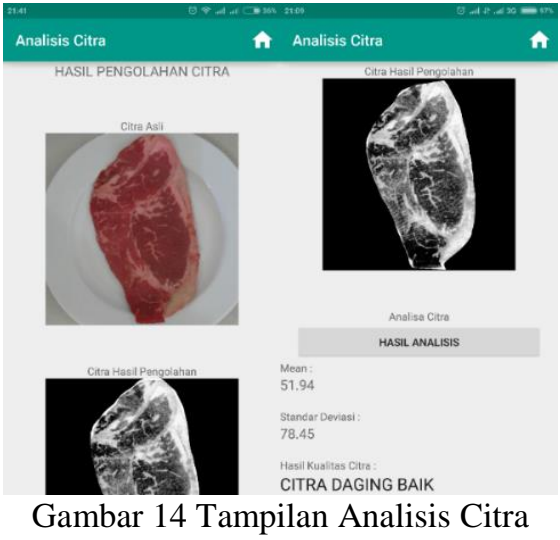

Pada halaman ini terdapat 2 (dua) buah citra berupa imageView yang ukurannya menyesuaikan dengan citra yang sudah di unggah sebelumnya. Untuk imageView pertama berisi citra asli yang isinya sama dengan imageView tampilan unggah citra. imageView kedua berisi citra hasil pengolahan dari tahap segmentsi citra berupa hasil pemilihan area terseleksi yang diubah dari citra aras keabuan menjadi citra aras keabuan terekualisasi histogram. Ekualisasi histogram tersebut berfungsi untuk menonjolkan area terseleksi berupa perataan intensitas keabuan yang dimiliki oleh citra agar lebih jelas. Selain itu terdapat textView yang berisi perhitungan mean dan standar deviasi dari citra hasil pengolahan berupa bilangan pecahan dengan 2 (dua) angka maksimal dibelakang koma. Pada bagian Action Bar yang memiliki tombol home yang mengarahkan kembali ke halaman utama jika pengolahan citra yang dilakukan sudah selesai.

7. Tampilan Bantuan

Tampilan Bantuan akan muncul saat pada halaman utama pengguna memilih tombol bantuan pada bagian kiri bawah. Berisi petunjuk penggunaan setiap tahapan 
proses pengolahan dari awal hingga akhir yang ditunjukkan pada gambar 15 .

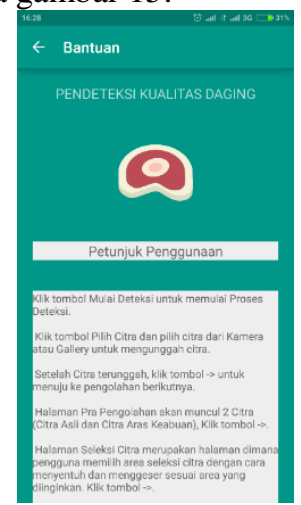

Gambar 15 Tampilan Bantuan

8. Tampilan Tentang

Tampilan Tentang akan muncul saat pada halaman utama pengguna memilih tombol tentang pada bagian kanan bawah. Berisi informasi tentang aplikasi yang ditunjukkan pada gambar 16.

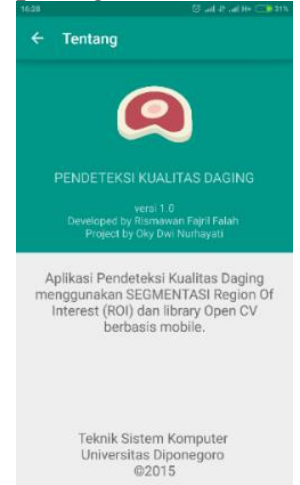

Gambar 16 Tampilan Tentang

\section{B. Hasi Penelitian}

Dalam penelitian ini tahap pengujian sistem dilakukan dengan melakukan pelatihan terhadap beberapa sampel data citra yang sudah dipilih dan dikumpulkan berdasarkan kriteria baik dan buruk dengan ekstensi citra .jpg. Terdapat 20 sampel data citra daging yang dipilih untuk dilakukan pelatihan pengujian sistem. Sampel diolah terlebih dahulu untuk memaksimalkan akurasi ketepatan penentuan daging baik dan buruk. Tahap pertama yaitu sampel diubah atau dikonversi menjadi citra aras keabuan, selanjutnya citra tersebut diseleksi berdasarka area yang diinginkan (Region of Interest). Terakhir citra terseleksi tersebut dikonversi ke citra aras keabuan terkeualisasi histogram. Ekualisasi histogram tersebut dapat meningkatkan akurasi ketepatan dari sampel citra daging tersebut.

Seluruh citra yang sudah selesai diolah satu per satu akan dicari nilai berdasarkan parameter mean dan standar deviasi. Hasil perhitungan kedua parameter tersebut digunakan untuk menentukan pengalokasian antara citra yang baik, rata-rata dan citra yang buruk. Perhitungan nilai statistik tersebut digunakan untuk membandingkan dengan aplikasi pengolahan citra lain. Penentuan kualitas daging ditentukan menggunakan pendekatan warna daging dan warna lemak pada standar daging sapi (SNI) dan dibandingkan dengan melihat kecocokan 20 sampel data citra yang sudah dipilih. Pada perbandingan dengan aplikasi pengolahan citra lain, selain membandingkan nilai statistik juga membandingkan kelebihan dan kekurangan fitur dari aplikasi yang dibuat.

1. Hasil olahan Citra Masukan

Hasil olahan pada setiap tahapan proses pengolahan citra dapat dijelaskan sebagai berikut:

a. Citra Asli

Citra asli diunggah sebagai masukan pada aplikasi dengan format citra RGB (24 bit) berekstensi .jpg yang dapat ditunjukkan pada gambar 17 .

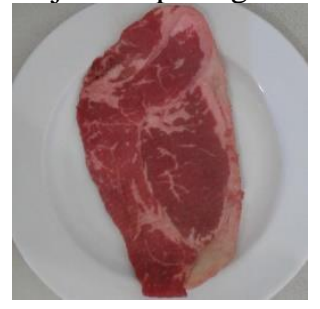

Gambar 17 Citra Asli

b. Citra Aras Keabuan

Citra asli dikonversi menjadi citra aras keabuan (8 bit) dengan ekstensi jpg yang dapat ditunjukkan pada gambar 18 .

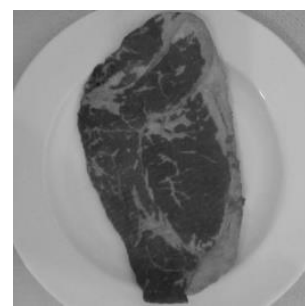

Gambar 18 Citra Aras Keabuan

c. Citra Keabuan Terseleksi

Citra aras keabuan diseleksi sesuai area yang diinginkan (Region of Interest) dengan ekstensi .PNG agar latar belakang citra menghilang yang dapat ditunjukkan pada gambar 19.

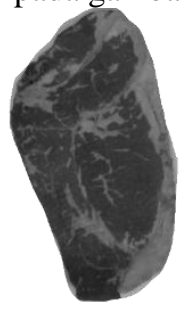

\section{Gambar 19 Citra Keabuan Terseleksi}

d. Citra Ekualisasi Histogram

Citra Terseleksi dikonversi ke Citra Ekualisasi Histogram dengan ekstensi .PNG yang dapat ditunjukkan pada gambar 20 .

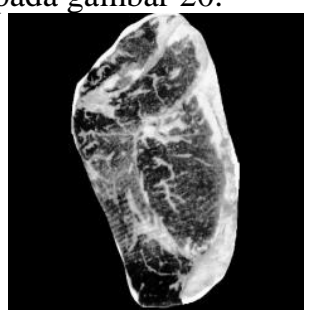

Gambar 20 Citra Ekualisasi Histogram 
2. Penentuan Parameter Kualitas Citra Daging

Menentukan suatu kualitas citra dibutuhkan sebuah perhitungan yang diambil dari parameter tertentu. Parameter menurut Kamus Besar Bahasa Indonesia (KBBI) berarti ukuran seluruh populasi dalam penelitian yang harus diperkirakan dari yang terdapat didalam percontoh. Parameter memiliki interpretasi yang lebih spesifik dalam matematika, logika, linguistik, ilmu lingkungandan disiplin ilmu lainnya. Parameter dilakukan melalui 2 (dua) tahapan yang dapat dijelaskan sebagai berikut.

\section{a. Penentuan Parameter Tahap 1}

Penentuan Parameter tahap 1 merupakan tahapan untuk menentukan penilaian kualitas daging sapi. Penentuan kualitas dapat dilakukan secara subjektif dan objektif. Penilaian secara subjektif meliputi penilaian terhadap warna, bau, keempukan dan cita rasa, sedangkan penilaian objektif dapat dilakukan dengan bantuan alat-alat laboratoris atau dengan standar perbandingan penilaian objektif meliputi penilaian terhadap $\mathrm{pH}$, kepulaman dan komposisi kimia daging. [13] Pada tahap 1 digunakan penentuan secara subjektif dari warna yang dilakukan berdasarkan Badan Standardisasi Nasional (SNI 3932:2008) ${ }^{[5]}$. Penentuan parameter diukur dari warna daging, warna lemakdan marbling. Terbagi menjadi 3 (tiga) tingkatan mutu daging yang dapat ditunjukkan pada tabel 1 .

Tabel 1 Tingkat Mutu Uji

\begin{tabular}{|c|c|c|c|c|}
\hline \multirow{2}{*}{ No } & \multirow{2}{*}{ Jenis Uji } & \multicolumn{3}{|c|}{ Persyaratan Mutu } \\
\hline & & $\mathrm{I}$ & II & III \\
\hline 1 & $\begin{array}{l}\text { Warna } \\
\text { Daging }\end{array}$ & $\begin{array}{c}\text { Merah } \\
\text { Terang } \\
\text { Skor } 1 \\
-5 \\
\end{array}$ & $\begin{array}{c}\text { Merah } \\
\text { Kegelapan } \\
\text { Skor } 6-7\end{array}$ & $\begin{array}{c}\text { Merah } \\
\text { Gelap } \\
\text { Skor } 8 \text { - } \\
9 \\
\end{array}$ \\
\hline 2 & $\begin{array}{l}\text { Warna } \\
\text { Lemak }\end{array}$ & $\begin{array}{l}\text { Putih } \\
\text { Skor } 1 \\
-3\end{array}$ & $\begin{array}{c}\text { Putih } \\
\text { Kekuningan } \\
\text { Skor } 4-6\end{array}$ & $\begin{array}{c}\text { Kuning } \\
\text { Skor } 7 \text { - } \\
9\end{array}$ \\
\hline 3 & Marbling & $\begin{array}{c}\text { Skor } 9 \\
-12\end{array}$ & Skor 5 - 8 & $\begin{array}{c}\text { Skor } 1 \text { - } \\
4\end{array}$ \\
\hline
\end{tabular}

Penilaian warna daging dilakukan dengan melihat warna permukaan otot mata rusuk dengan bantuan cahaya senter dan mencocokkan dengan standar warna. Nilai skor warna ditentukan berdasarkan skor standar warna yang paling sesuai dengan warna daging. Standar warna daging terdiri atas 9 (Sembilan) skor mulai dari warna merah muda hingga merah tua yang dapat ditunjukkan pada Gambar 21.

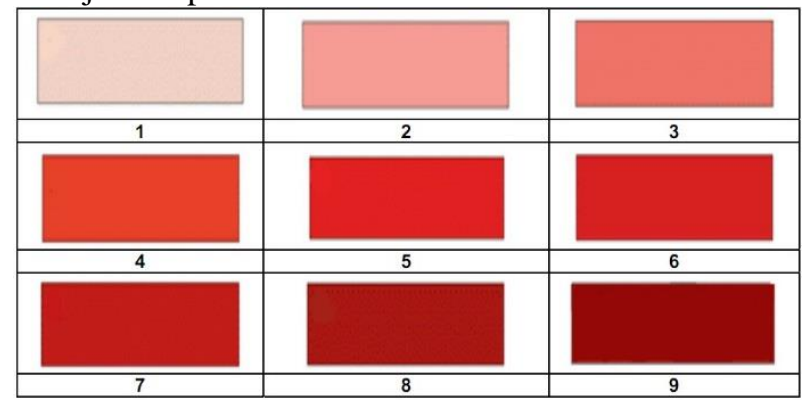

Gambar 21 Standar Warna Daging Sapi
Penilaian warna lemak dilakukan dengan melihat warna lemak subkutis (lapisan terdalam kulit) dengan bantuan cahaya senter dan mencocokkan dengan standar warna. Nilai skor warna ditentukan berdasarkan skor standar warna yang paling sesuai dengan warna lemak. Standar warna lemak terdiri atas 9 (Sembilan) skor mulai dari warna putih hingga kuning yang dapat ditunjukkan pada Gambar 22.

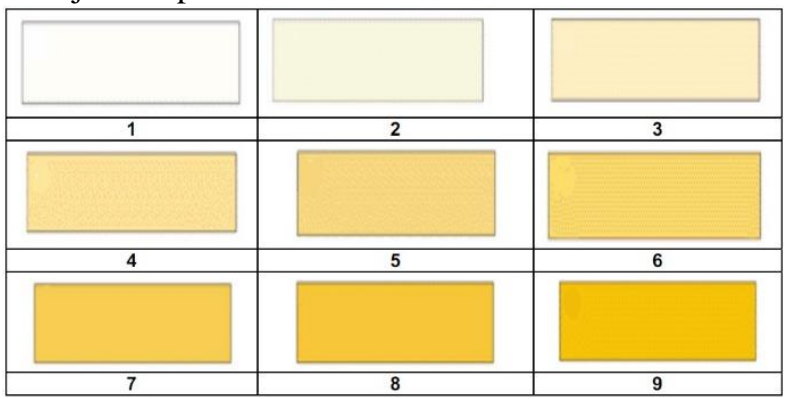

Gambar 22 Standar Warna lemak

Penilaian marbling dilakukan dengan melihat intensitas marbling pada permukaaan otot mata rusuk dengan bantuan cahaya senter dan mencocokkan dengan standar marbling. Sejauh ini belum ditemukan cara menentukan penilaian marbling berdasarkan nilai statistik ekstraksi ciri. Nilai skor marbling ditentukan berdasar skor standar marbling yang paling sesuai dengan intensitas marbling otot mata rusuk. Marbling terdiri atas 12 (dua belas) skor mulai dari praktis tidak ada marbling hingga banyak yang dapat ditunjukkan pada Gambar 23.

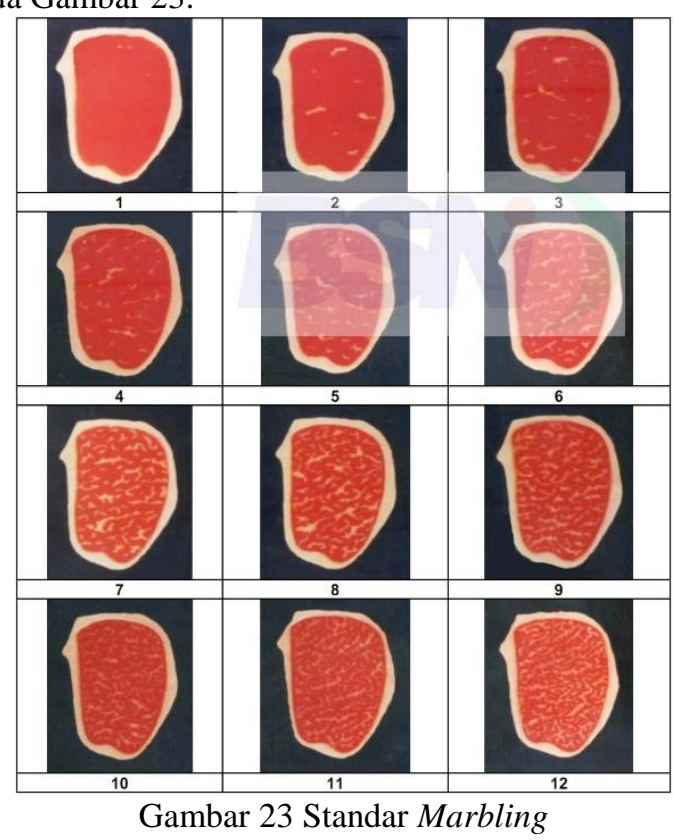

b. Penentuan Parameter Tahap 2

Penentuan Parameter tahap 2 merupakan tahapan untuk menerapkan parameter kualitas daging yang sudah didapat dari tahap 1. Penentuan dilakukan pada 20 sampel data citra yang sudah dipilih sebelumnya secara acak. [14] Sampel-sampel tersebut ditentukan berdasarkan pendekatan warna daging, warna lemak. Hasil dapat ditunjukkan pada tabel 2. 
Tabel 2 Hasil Penentuan Mutu Menggunakan Pendekatan Warna Pada Sampel Data Citra

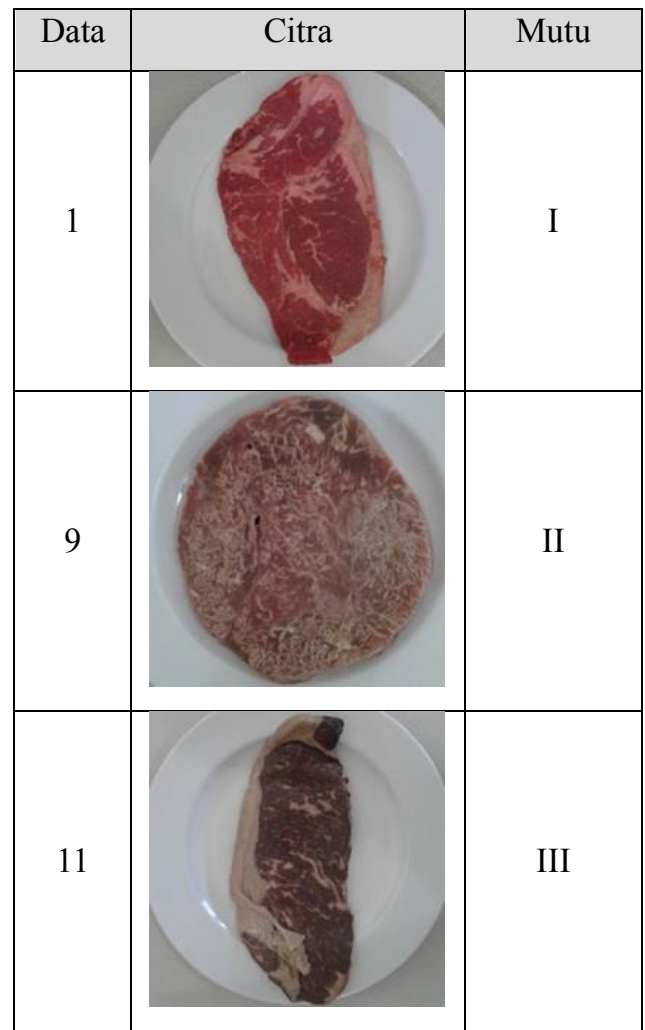

Data citra daging sapi (20 sampel data) didapatkan 2 (dua) data memiliki kualitas mutu daging I / baik (Data 1 dan 2), 4 (empat) data memiliki kualitas mutu daging II / rata-rata (Data 9, 10, 15 dan 16) dan data lainnya yaitu 14 (empat belas) data memiliki kualitas mutu daging III / Buruk.

\section{Perbandingan Statistik Citra}

Perbandingan Statistik Citra merupakan tahapan dalam penelitian setelah menentukan parameter kualitas citra daging. Dalam tahap ini akan dijelaskan mengenai ekstraksi ciri atau analisis citra daging serta membandingkan hasil analisa dengan hasil analisis dari aplikasi pengolahan citra lainnya (Fiji / ImageJ). 20 sampel data citra daging yang sudah ditentukan kualitasnya tersebut masing-masing diproses atau diolah dari citra asli $\rightarrow$ citra aras keabuan $\rightarrow$ citra aras keabuan di seleksi area (Region of Interest) $\rightarrow$ citra ekualisasi histogram $\rightarrow$ analisis citra hasil. Hasil analisis citra menggunakan aplikasi pendeteksi kualitas daging berbasis mobile yang sudah dibuat ditunjukkan pada tabel 3.

Tabel 3 Hasil Analisa Menggunakan Aplikasi

Pendeteksi Daging Berbasis Mobile

\begin{tabular}{|c|r|r|r|r|}
\hline \multirow{2}{*}{ Data } & \multirow{2}{*}{ Citra Asli } & \multirow{2}{*}{ Citra Hasil } & \multicolumn{2}{|c|}{ Analisis Citra } \\
\cline { 4 - 5 } & & & Mean & $\begin{array}{c}\text { Standar } \\
\text { Deviasi }\end{array}$ \\
\hline & & & & \\
& & & & \\
& & & & \\
& & & & \\
\end{tabular}

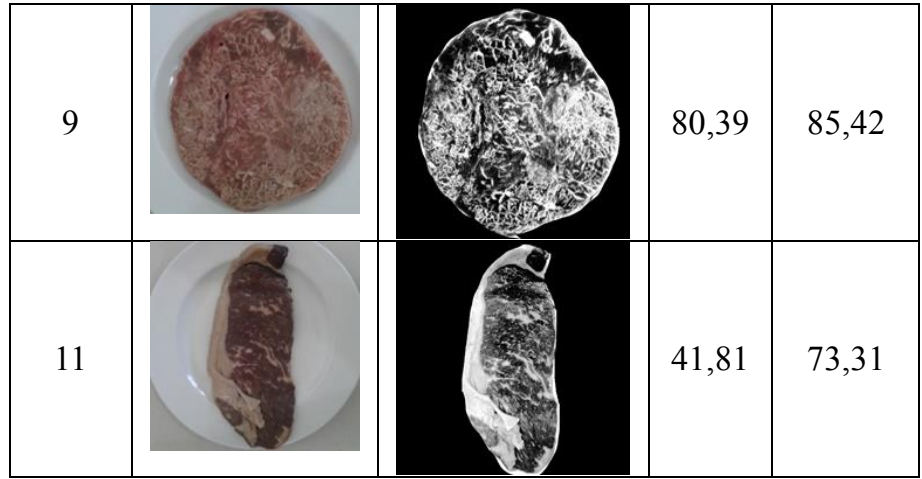

Hasil analisis citra menggunakan aplikasi Fiji atau ImageJ ditunjukkan pada tabel 4.

Tabel 4 Hasil Analisa Menggunakan Aplikasi Fiji atau Image J

\begin{tabular}{|c|c|c|c|c|}
\hline \multirow[b]{2}{*}{ Data } & \multirow[b]{2}{*}{ Citra Asli } & \multirow[b]{2}{*}{ Citra Hasil } & \multicolumn{2}{|c|}{ Analisis Citra } \\
\hline & & & Mean & $\begin{array}{l}\text { Standar } \\
\text { Deviasi }\end{array}$ \\
\hline 1 & & & 107,45 & 64,27 \\
\hline 9 & & & 123,39 & 61,15 \\
\hline 11 & & & 111,42 & 67,27 \\
\hline
\end{tabular}

Berdasarkan hasil pelatihan menggunakan aplikasi pendeteksi kualitas daging berbasis mobile dan aplikasi Fiji atau ImageJ dengan menggunakan proses pengolahan yang sama dapat dihasilkan keluaran nilai statistic mean dan standar deviasi yang berbeda. Masing-masing memiliki kelebihan dan kekurangan dalam proses pengukurannya. Faktor yang mempengaruhi perbedaan adalah sebagai berikut.

- Proses seleksi area atau cropping yang berbeda posisinya

- Hasil pemotongan memiliki perbedaan yang signifikan. Pada Aplikasi yang dibuat, proses seleksi mampu menghilangkan latar belakang atau area nonseleksi. Sedangkan pada Fiji atau ImageJ proses seleksi tetap menyertakan latarbelakang pada area sekitar seleksi.

Faktor tersebut membuat citra ekualisasi histogram yang merupakan citra pengolahan terakhir hasilnya juga berbeda. Hal tersebut mempengaruhi nilai statistik dari citra tersebut dan mengakibatkan hasil yang berbeda. Dari hasil yang didapat juga mempengaruhi akurasi ketepatan baca untuk menentukan daging berkualitas baik atau buruk. Untuk menentukan akurasi ketepatan 
baca digunakan rumus yang ditunjukkan dengan persamaan (1).

Akurasi $=100 \%-\frac{\text { Data menyimpang }}{\text { jumlah data }} * 100 \%$

Akurasi ketepatan baca dari masing-masing aplikasi dapat ditunjukkan sebagai berikut.

a. Aplikasi Pendeteksi Kualitas Daging Berbasis Mobile

Sampel data citra daging di bagi sesuai kualitas mutu yang dihasilkan. Pada setiap kualitas mutu diambil nilai maksimal dan minimal dari perhitungan statistik yang sudah dihasilkan sebelumnya. Dari hasil tersebut didapatkan rentang nilai statistik dari masing-masing kualitas mutu daging yang ditunjukkan pada tabel 5 .

Tabel 5 Rentang Mean dan Standar Deviasi setiap mutu daging (Aplikasi Mobile)

\begin{tabular}{|c|c|c|}
\hline \multirow{2}{*}{$\begin{array}{c}\text { Mutu } \\
\text { Daging }\end{array}$} & \multicolumn{2}{|c|}{ Rentang } \\
\cline { 2 - 3 } & Mean & $\begin{array}{c}\text { Standar } \\
\text { Deviasi }\end{array}$ \\
\hline I & $49-53$ & $77-79$ \\
\hline II & $80-85$ & $85-86$ \\
\hline III & $\begin{array}{c}\text { Mean }<49 \\
\text { dan } \\
\text { Mean }>85\end{array}$ & $\begin{array}{c}\text { St Dev }<77 \\
\text { dan } \\
\text { St Dev }>86\end{array}$ \\
\hline
\end{tabular}

Pada hasil penelitian didapatkan 2 (dua) nilai statistik kualitas mutu III / buruk yang menyimpang dan masuk dalam rentang kualitas mutu I / baik (Data 13 dan Data 14). Penentuan akurasi dapat dihitung.

$$
\begin{aligned}
\text { Akurasi }=100 \% & -\frac{2}{20} * 100 \%=100 \%-10 \% \\
& =90 \%
\end{aligned}
$$

Akurasi yang dihasilkan menggunakan aplikasi ini memiliki ketepatan baca kualitas daging sebesar $90 \%$.

b. Aplikasi Fiji atau ImageJ

Sampel data citra daging di bagi sesuai kualitas mutu yang dihasilkan. Pada setiap kualitas mutu diambil nilai maksimal dan minimal dari perhitungan statistic yang sudah dihasilkan sebelumnya. Dari hasil tersebut didapatkan rentang nilai statistik dari masing-masing kualitas mutu daging yang ditunjukkan pada tabel 6 .

Tabel 6 Rentang Mean dan Standar Deviasi setiap mutu daging (Aplikasi Fiji)

\begin{tabular}{|c|c|c|}
\hline \multirow{2}{*}{$\begin{array}{c}\text { Mutu } \\
\text { Daging }\end{array}$} & \multicolumn{2}{|c|}{ Rentang } \\
\cline { 2 - 3 } & Mean & $\begin{array}{c}\text { Standar } \\
\text { Deviasi }\end{array}$ \\
\hline I & $107-108$ & $63-65$ \\
\hline II & $117-124$ & $60-62$ \\
\hline \multirow{3}{*}{ III } & Mean $<107$ & St Dev $<60$ \\
& $108,1-116,9$ & $62,1-62,9$ \\
& Mean $>124$ & St Dev $>65$ \\
\hline
\end{tabular}

Pada hasil penelitian tidak didapatkan nilai statistik yang menyimpang dan masuk dalam rentang kualitas mutu lainnya. Penentuan akurasi dapat dihitung.

$$
\begin{gathered}
\text { Akurasi }=100 \%-\frac{0}{20} * 100 \%=100 \%-0 \% \\
=100 \%
\end{gathered}
$$

Akurasi yang dihasilkan menggunakan aplikasi ini memiliki ketepatan baca kualitas daging sebesar $100 \%$.

\section{Pengujian Program}

Pengujian "Aplikasi Pendeteksi Kualitas Daging Menggunakan Segmentasi Region of Interest Berbasis Mobile" dilakukan dengan menggunakan pengujian black box. Pengujian dilakukan untuk melihat fungsifungsi dari antarmuka aplikasi mampu berjalan dengan baik atau tidak. Hasil dari pengujian fungsi pada aplikasi ini, dapat dilihat pada tabel 7 .

\begin{tabular}{|c|c|c|}
\hline No. & Fungsi & Hasil Uji \\
\hline 1 & $\begin{array}{l}\text { Menampilkan halaman Menu } \\
\text { Utama }\end{array}$ & Berhasil \\
\hline 2 & $\begin{array}{l}\text { Pemilihan menu Mulai } \\
\text { Deteksi }\end{array}$ & Berhasil \\
\hline 3 & $\begin{array}{l}\text { Menampilkan halaman } \\
\text { Unggah Citra }\end{array}$ & Berhasil \\
\hline 4 & Pemilihan tombol Pilih Citra & Berhasil \\
\hline 5 & $\begin{array}{l}\text { Pemilihan tombol Kamera dan } \\
\text { tampil kamera }\end{array}$ & Berhasil \\
\hline 6 & $\begin{array}{l}\text { Pemilihan tombol Gallery dan } \\
\text { tampil Gallery }\end{array}$ & Berhasil \\
\hline 7 & $\begin{array}{l}\text { Pemilihan tombol panah } \rightarrow \\
\text { dan } \leftarrow \text { (halaman Unggah } \\
\text { Citra) }\end{array}$ & Berhasil \\
\hline 8 & $\begin{array}{l}\text { Menampilkan halaman Pra } \\
\text { pengolahan }\end{array}$ & Berhasil \\
\hline 9 & $\begin{array}{l}\text { Pemilihan tombol panah } \rightarrow \\
\text { (halaman Pra Pengolahan) }\end{array}$ & Berhasil \\
\hline 10 & $\begin{array}{l}\text { Menampilkan halaman } \\
\text { Seleksi Citra }\end{array}$ & Berhasil \\
\hline 11 & Pemilihan area citra & Berhasil \\
\hline 12 & $\begin{array}{l}\text { Menampilkan halaman } \\
\text { Segmentasi Citra }\end{array}$ & Berhasil \\
\hline 13 & $\begin{array}{l}\text { Pemilihan tombol panah } \rightarrow \\
\text { (halaman Segmentasi Citra) }\end{array}$ & Berhasil \\
\hline 14 & $\begin{array}{l}\text { Menampilkan halaman } \\
\text { Analisis Citra }\end{array}$ & Berhasil \\
\hline 15 & $\begin{array}{l}\text { Pemilihan tombol Analisis } \\
\text { citra }\end{array}$ & Berhasil \\
\hline 16 & $\begin{array}{l}\text { Menampilkan perhitungan } \\
\text { analisis citra }\end{array}$ & Berhasil \\
\hline 17 & Pemilihan tombol Home & Berhasil \\
\hline 18 & Pemilihan menu Bantuan & Berhasil \\
\hline 19 & $\begin{array}{l}\text { Menampilkan Halaman } \\
\text { Bantuan }\end{array}$ & Berhasil \\
\hline 20 & $\begin{array}{l}\text { Pemilihan tombol panah } \leftarrow \\
\text { (halaman Bantuan) }\end{array}$ & Berhasil \\
\hline 21 & Pemilihan menu Tentang & Berhasil \\
\hline 22 & $\begin{array}{l}\text { Pemilihan tombol panah } \leftarrow \\
\text { (halaman Tentang) }\end{array}$ & Berhasil \\
\hline 23 & Pemilihan menu Keluar & Berhasil \\
\hline
\end{tabular}

Tabel 7 Hasil Pengujian Fungsi Pada Aplikasi Pendeteksi Kualitas Daging 


\section{A. Kesimpulan}

\section{PENUTUP}

Berdasarkan hasil pengujian dan analisis pembuatan aplikasi dapat disimpulkan sebagai berikut :

1. Aplikasi yang dibuat pada tugas akhir ini dapat mengolah citra dari sampel data citra atau gambar yang dapat diunggah dari Gallery menggunakan proses pengolahan citra ekualisasi histogram dan Region of Interest (ROI).

2. Region of Interest (ROI) memungkinkan pengguna aplikasi untuk menentukan area yang akan diseleksi sesuai keinginan atau yang dibutuhkan saja.

3. Parameter kualitas daging dapat ditentukan dengan proses pendekatan warna daging dan warna lemak sesuai SNI untuk menentukan tingkatan mutu pada sampel data citra.

4. Hasil perbandingan antara aplikasi Pendeteksi Kualitas Daging Berbasis Mobile dengan aplikasi Fiji atau ImageJ ditentukan berdasarkan nilai statistik mean dan standar deviasi.

5. Perbandingan didapatkan aplikasi Pendeteksi Kualitas Daging Berbasis Mobile memiliki akurasi ketepatan baca kualitas daging yaitu sebesar $90 \%$ ketepatan dan aplikasi Fiji atau ImageJ memiliki akurasi sebesar $100 \%$.

\section{B. Saran}

Berdasarkan hasil pengujian dan analisis pembuatan aplikasi terdapat saran untuk pengembangan aplikasi selanjutnya.

1. Penentuan parameter kualitas daging hanya dengan menggunakan pendekatan warna masih kurang akurat. Dibutuhkan cara lain untuk penentuan yang lebih akurat.

2. Perlu proses analisis yang lain untuk mengukur keakuratan aplikasi yang dibangun seperti nilai statistik skewness, kutosisdan entropy serta pada nilai statistik orde kedua.

3. Proses seleksi area (Region of Interest) yang dibuat secara otomatis (auto-selection) untuk mempermudah pengambilan citra yang sesuai.

4. Memperluas parameter kualitas citra daging lebih dari 3 (tiga) agar pengguna mampu melihat hasil yang lebih spesifik dari pada hanya citra mutu I, II dan III.

5. Pengembangan aplikasi yang lebih meluas untuk berbagai perangkat bergerak jenis lain seperti iOS, Blackberry OS, Windows Phone dan lainnya.

\section{DAFTAR PUSTAKA}

[1] W. Nurhayat, "BPS: Tahun Depan Permintaan Daging Sapi Naik 8\% Jadi 639.000 Ton," detikcom, 23 Desember 2014. [Online]. Available: http://finance.detik.com. [Accessed 29 April 2015].

[2] P. Yulianto, "Peningkatan Citra Untuk Memperjelas Foto Brain CT Scan," Jurnal Ilmiah Semesta Teknika, vol. XI, 2008.

[3] S. Ilmu dan Teknologi Daging, Yogyakarta: Gajah Mada University Press, 2005.

[4] R. A. Lawrie, Lawrie's Meat Sciene, Cambridge: Woodhead Publishing Ltd., 1998.

[5] B. S. Nasional, "Mutu Karkas dan Daging Sapi," SNI 3932:2008, 2008

[6] S. Usmiati, Pengawtan Daging Segar dan Olahan, Bogor: Balai Besar Penelitian dan Pengembangan Pascapanen Pertanian, 2010.

[7] D. Putra, Pengolahan Citra Digital, Yogyakarta: Penerbit ANDI, 2010.

[8] E. Prasetyo, Pengolahan Citra digital dan Aplikasinya Menggunakan Matlab, Yogyakarta: Penerbit ANDI, 2011.

[9] O. D. Nurhayati and A. Susanto, "Penerapan Metode Segmentasi Pada Analisis Citra Digital Head CT-Scan," Disertasi. Universitas Gajah Mada, Yogyakarta, 2008.

[10] A. Muharom, R. Cahyana and Bunyamin M.Kom, "Pengembangan Aplikasi Sunda Berbasis Android Menggunakan Metode Rapid Application Development (RAD)," Jurnal ALgoritma, 2013.

[11] N. Safaat H, Android : Pemrograman Aplikasi Mobile Smartphone dan Tablet PC, Bandung: Informatika, 2012.

[12] G. Bradski and A. Kaehler, Learning OpenCV, Sebastopol, US: O'Reilly Media, Inc, 2008.

[13] Arka, "Ilmu Pengetahuan Daging dan Teknologinya," Universitas Udayana, Denpasar, 1994.

[14] K. Adi, S. Pujiyanto, O. D. Nurhayati and A. Pamungkas, "Beef Quality Identification using Color Analysis and K-Nearest Neighbor Classification," in International Conference on Instrumentation, Communications, Information Technology, and Biomedical Engineering (ICICI-BME), Bandung, Indonesia, 2015. 